The Free Internet Journal

for Organic Chemistry
Paper

Arkivoc 2017, part iv, 184-193

\title{
Synthesis of furo[2',3':4,5]pyrrolo[1,2-d][1,2,4]triazine derivatives and their antibacterial activity
}

\author{
Ivana Zemanová, ${ }^{a}$ Renata Gašparová, ${ }^{a *}$ Filip Kraic, ${ }^{c}$ Dáša Kružlicová, ${ }^{a}$ Tibor Maliar, ${ }^{b}$ Andrej Boháč, ${ }^{d}$ and \\ Gabriela Addováe
}

${ }^{a}$ Department of Chemistry and ${ }^{b}$ Department of Biotechnologies, Faculty of Natural Sciences, University of Ss.

Cyril and Methodius, Námestie. J. Herdu 2, 91701 Trnava, Slovak Republic

'Saneca Pharmaceuticals, Nitrianska 100, 92001 Hlohovec, Slovak Republic

${ }^{d}$ Department of Organic Chemistry and e Institute of Chemistry, Faculty of Natural Sciences, Comenius

University, Ilkovičova 6, 84215 Bratislava, Slovak Republic

E-mail: renata.gasparova@ucm.sk

Received 07-08-2016

Accepted 04-27-2017

Published on line 05-14-2017

\section{Abstract}

Furo[2',3':4,5]pyrrolo[1,2-d][1,2,4]triazin-8(7H)-ones 5 were synthesized either by reaction of carbohydrazide 2 with triethyl orthoesters or by acetylation of methyl $4 H$-furo[3,2-b]pyrrole-5-carboxylate 1 followed by thionation of 4-acetylfuro[3,2-b]pyrrole-5-carboxylate $\mathbf{3}$ and cyclisation of thione $\mathbf{4}$ with hydrazine. Triazine 5a afforded the corresponding thione 7 by reaction with $\mathrm{P}_{2} \mathrm{~S}_{5}$. Upon reaction with alkyl- or acylhalogenides compounds 5 and $\mathbf{7}$ gave $N(7)$-substituted products $\mathbf{6}$ and 8, respectively. Finally, triazino-triazinone derivative $\mathbf{9}$ was synthesized by cyclisation of thione $\mathbf{8 b}$ with hydrazine. Compounds $\mathbf{5}$ - $\mathbf{9}$ were evaluated for their antibacterial activity.

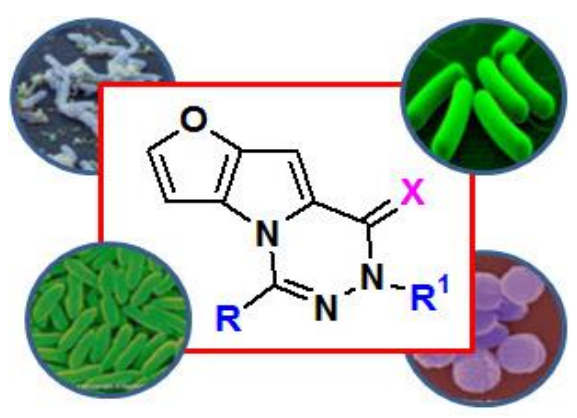

Keywords: Furo[3,2-b]pyrrole, triazine, orthoester, cyclisation, thione, antibacterial activity 


\section{Introduction}

The synthesis and the study of physical and chemical properties of pyrrolo-fused heteroaryl compounds, such as furo-, thieno- and selenopyrroles has been well documented over the last few decades. Furo[3,2-b]pyrroles are isosteres of the indole ring system in which the benzene ring is replaced by the furan ring. Efficient synthetic routes to these heterocycles are of great interest ${ }^{1-4}$ as the furo[3,2-b]pyrrole core has been found in compounds with diverse biological activities ${ }^{5-7}$ or they are used as the fluorescent dyes ${ }^{8}$.

Heterocyclic compounds containing five- and six-membered nitrogen heterocyclic rings have also attracted the attention due to the fact that they exhibit many biological interactions ${ }^{9,10}$. In addition, 1,2,4-triazin-6-one is structural system found in numerous natural and synthetic biologically active compounds with a wide range of biological activities including anti-inflammatory, ${ }^{11}$ antifungal, ${ }^{10}$ antiviral, ${ }^{12}$ anti-HIV ${ }^{13}$ or anticonvulsant. ${ }^{14}$

Among tricyclic 5-5-6 fused ring heterocycles only thieno[3,2-b]pyrrole[3,2- $d]$ pyridazinones and pyrimidinones ${ }^{15}$ and furo[2', $\left.3^{\prime}: 4,5\right]$ pyrrolo[1,2-d] $[1,2,4]$ triazin- $8(7 H)$-ones ${ }^{16}$ have been synthesized and only these thieno-derivatives were evaluated for their anticancer activity. Therefore we are interested in the chemistry of the 1,2,4-triazine ring fused on its 4-5 bond with furo[3,2-b]pyrrole system. In our continuing efforts towards the synthesis and biological activity of furo[3,2-b]pyrrole derivatives we are interested in a synthesis of 5- and 7-substituted furo[3,2-b]pyrrole derivatives fused with six-membered heterocyclic ring and their antibacterial activity against selected strains of $\mathrm{G}^{+}$and $\mathrm{G}^{-}$bacteria.

\section{Results and Discussion}

Generally, the construction of 1,2,4-triazin-6-one moiety can be reached by two main strategies. The first one is based on the cyclocondensation of $\alpha$-aminocarbohydrazide with an orthoester. ${ }^{16,17}$ The second method involves the cyclisation of $N$-thioacyl- $\alpha$-aminoester with hydrazine. ${ }^{18}$

The title compounds 5 are well accessible ${ }^{16,19}$ from methyl $4 H$-furo[3,2-b]pyrrole-5-carboxylate 1 via its transformation to carbohydrazide $\mathbf{2}$. Hydrazinolysis was achieved in $80 \%$ yield by heating of $\mathbf{1}$ with hydrazine hydrate in ethanol for $20 \mathrm{~h}^{16}$. Subsequently, the construction of 1,2,4-triazine ring of 5 was taken place by the cyclization of $\mathbf{2}$ with orthoesters (triethyl orthoformate, triethyl orthochloroacetate or triethyl orthoacetate) (Scheme 1, path a) in dimethylformamide. Resulting furo[2',3':4,5]pyrrolo[1,2-d][1,2,4]triazin-8(7H)-ones 5a-5c were obtained in $69-75 \%$ yields. Compounds $\mathbf{5 a}-\mathbf{5 c}$ display in their ${ }^{1} \mathrm{H}$ NMR spectra the singlet at $11.65-12.09$ ppm due to $\mathrm{NH}$ group. The $\mathrm{H}-2$ and $\mathrm{H}-9$ protons resonate as doublets at 8.00-7.97 ppm $(J=2.1 \mathrm{~Hz})$ and 6.88 $7.17 \mathrm{ppm}(J=2.4 \mathrm{~Hz})$ regions, respectively. IR Spectra of $\mathbf{5 a - 5 c}$ exhibit absorption band of C-8 carbonyl group at $1639-1642 \mathrm{~cm}^{-1} .{ }^{13} \mathrm{C}$ NMR spectra of 5a-5c display the C-8 carbonyl carbons in the region 154.4-155.2 ppm and C-5 carbons at 138.2-148.4 ppm.

In order to exploit the new route to the formation of triazine ring of $5 c$, we have realized $N$-acetylation of 1 by method of Krutošíková ${ }^{20}$ in acetic anhydride for $4 \mathrm{~h}$, when methyl $\mathrm{N}$-acetylfuro[3,2-b]pyrrole-5-carboxylate 3 was obtained in $60 \%$ yield. Compound $\mathbf{3}$ was subsequently converted to the corresponding thione $\mathbf{4}$ in $60 \%$ yield by reaction with phosphorus pentasulfide in pyridine for $10 \mathrm{~h}$. Finally, thione 4 cyclised into $5 \mathrm{c}$ in $65 \%$ yield by heating with hydrazine hydrate in ethanol (Scheme 1, path b). 

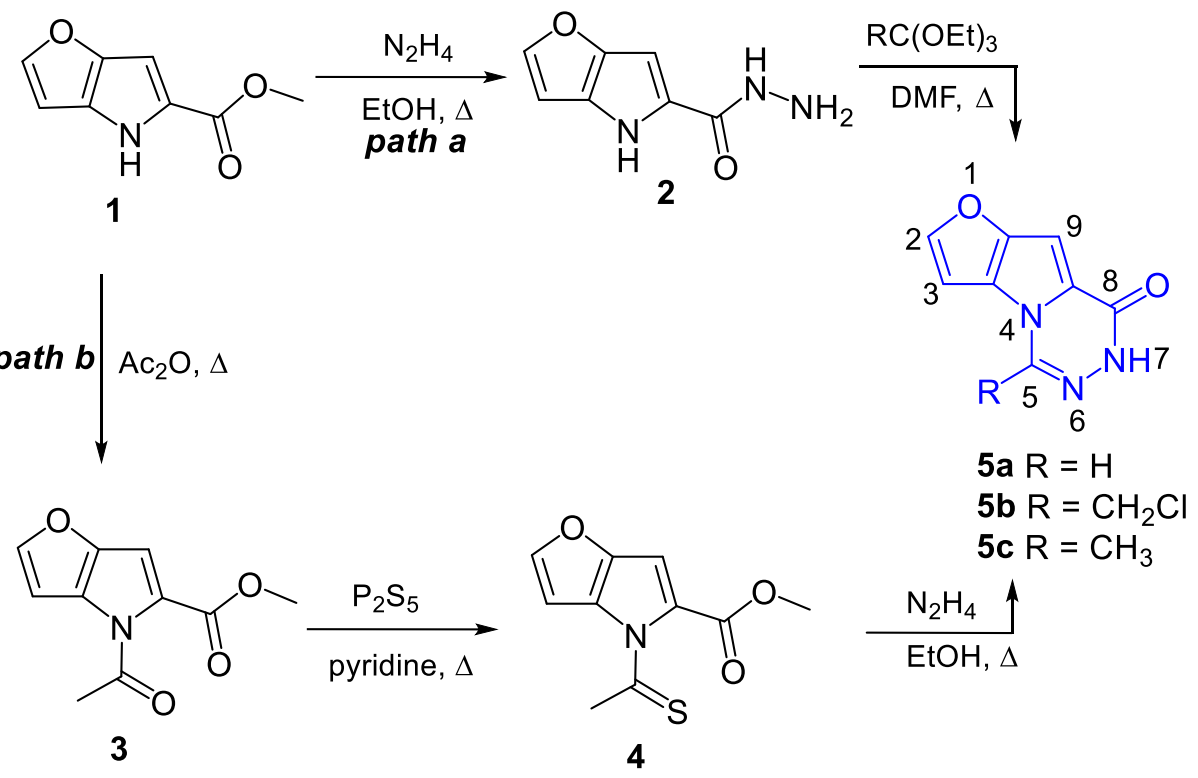

Scheme 1. Synthesis of triazine derivatives 5

Although the yields of $5 \mathrm{c}$ by the path $b(65 \%)$ and the path $a(71 \%)$, were comparable, path $b$ requires long reaction time (168h) and this fact limits the applicability of this approach.

Compound 3 displays in its ${ }^{1} \mathrm{H}$ NMR spectrum doublet due to $\mathrm{H}-2$ proton at $7.79 \mathrm{ppm}(J=2.4 \mathrm{~Hz})$, doublet of doublets of the pyrrole $\mathrm{H}-6$ proton at $6.76 \mathrm{ppm}(J=2.4,0.9 \mathrm{~Hz})$ and doublet of the $\mathrm{H}-3$ proton at $6.61 \mathrm{ppm}(J$ $=2.4,0.9 \mathrm{~Hz}$ ). The most distinct signals of 3 in the ${ }^{13} \mathrm{C}$ NMR spectrum were the carbonyl carbons at 168.9 and $162.1 \mathrm{ppm}$.

Alkylation of triazine $5 \mathrm{a}$ with alkylhalides $\left(\mathrm{CH}_{3} \mathrm{l}, \mathrm{n}-\mathrm{C}_{6} \mathrm{H}_{9} \mathrm{Br}, \mathrm{ClCH}_{2} \mathrm{COOEt}\right)$ in dimethylformamide in the presence of sodium hydride at room temperature for 2.5-6 $\mathrm{h}$ provided 7-alkyl[2',3':4,5]pyrrolo[1,2d] $[1,2,4]$ triazin-8(7H)-ones $\mathbf{6 a}, \mathbf{6 b}$ and $\mathbf{6 d}$ in $45-72 \%$ yields (Scheme 2). Synthesis of 7benzyl[2',3':4,5]pyrrolo[1,2-d][1,2,4]triazin-8(7H)-one $6 c$ required higher temperature $\left(55{ }^{\circ} \mathrm{C}\right)$ and the derivative $6 \mathrm{c}$ was obtained in low yield $(27 \%)$ after heating overnight. 7-Acetylated compound $6 \mathrm{e}$ was synthesized in $53 \%$ yield by refluxing of $5 \mathrm{a}$ in acetic anhydride for $1.5 \mathrm{~h}$.

The structures of compounds $6 \mathrm{a}-6 \mathrm{e}$ were established by ${ }^{1} \mathrm{H}$ NMR, ${ }^{13} \mathrm{C}$ NMR and IR spectroscopy. They display in their ${ }^{1} \mathrm{H}$ NMR spectra, in addition to other signals, singlets of $\mathrm{H}-5$ protons at 8.81-8.83 ppm, doublets of the pyrrole $\mathrm{H}-2$ protons in the region of 7.99-8.09 ppm $(J=2.4 \mathrm{~Hz}), \mathrm{H}-3$ protons resonate as doublets of doublets at 7.09-7.11 ppm $(J=2.1,0.9 \mathrm{~Hz})$. The $\mathrm{H}-9$ protons appear as singlets at 7.14-7.20 ppm. ${ }^{13} \mathrm{C} \mathrm{NMR}$ spectra show the signals of C-8 carbonyl carbons at 153.9-154.6 ppm, region, signals of C-5 carbon at 149.7$151.6 \mathrm{ppm}$ region. In the spectrum of $6 \mathrm{e}$ there is the signal of the carbonyl carbon of acetyl group at 170.6 $\mathrm{ppm}$ and carbonyl carbon of methoxycarbonyl group of $\mathbf{6 d}$ appears at $168.2 \mathrm{ppm}$. The characteristic bands observed at $1641-1652 \mathrm{~cm}^{-1}$ in IR spectra correspond to the $\mathrm{C}=0$ groups at $\mathrm{C}-8$. 

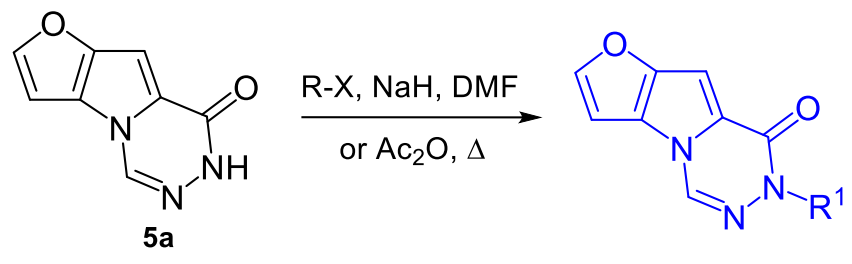

$$
\begin{aligned}
\mathbf{6 a ~ R} \mathrm{R}^{1} & =\mathrm{CH}_{3} \\
\mathbf{6 b} \mathrm{R}^{1} & =\mathrm{n}-\mathrm{C}_{4} \mathrm{H}_{9} \\
\mathbf{6} \mathrm{c}^{1} & =\mathrm{CH}_{2} \mathrm{C}_{6} \mathrm{H}_{5} \\
\mathbf{6 d ~ R} \mathrm{R}^{1} & =\mathrm{CH}_{2} \mathrm{COOCH}_{3}
\end{aligned}
$$

6e $\mathrm{R}^{1}=\mathrm{COCH}_{3}$
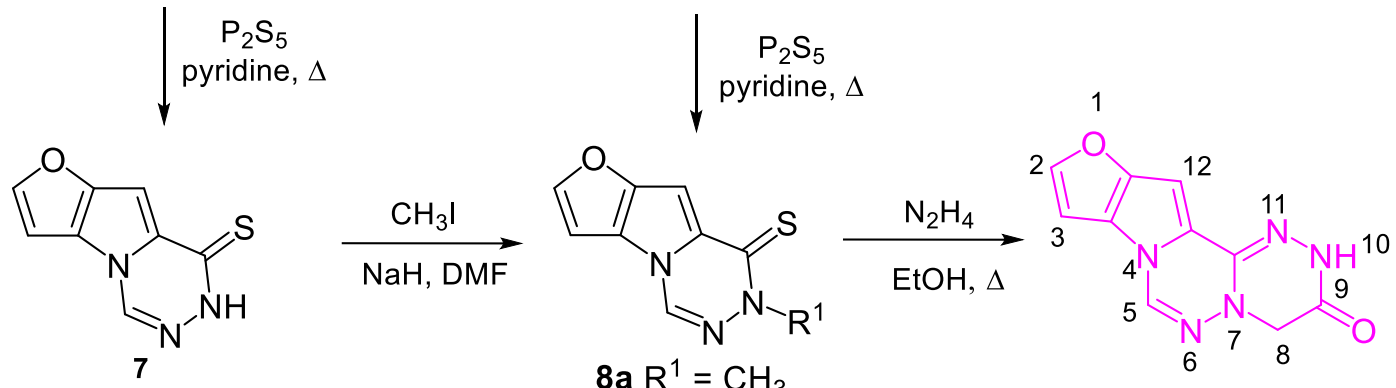

8a $\mathrm{R}^{1}=\mathrm{CH}_{3}$

$8 \mathbf{b} \mathrm{R}^{1}=\mathrm{CH}_{2} \mathrm{COOCH}_{3}$

9

Scheme 2. Synthesis of triazines 6-8 and triazino-triazinone $\mathbf{9 .}$

The carbonyl group at C-8 of triazine ring of 5 a can be easily thionated ${ }^{1,16}$ by reaction with phosphorus pentasulfide in pyridine to give thione 7 in high yield (85\%). Subsequent reaction of 7 with methyl iodide in dimethylformamide in the presence of sodium hydride at room temperature for $1 \mathrm{~h}$ led to 7methylfuro[2',3':4,5]pyrrolo[1,2-d][1,2,4]triazine-8(7H)-thione $\mathbf{8 a}$ in $76 \%$ yield. Synthesis of $8 \mathbf{a}$ as well as $8 \mathbf{b}$ was also achieved from $\mathrm{N}(7)$-substituted derivatives $6 \mathrm{a}, 6 \mathrm{~d}$ which were thionated with $\mathrm{P}_{2} \mathrm{~S}_{5}$ in pyridine for 5-9h. The yield of $\mathbf{8 a}$ was slightly lower $(67 \%)$ in comparison to the inverse reaction sequence and thione $\mathbf{8 b}$ was synthesized in $71 \%$ yield (Scheme 2 ).

The structures of compounds 7 and 8 were established by ${ }^{1} \mathrm{H}$ NMR, ${ }^{13} \mathrm{C}$ NMR and IR spectroscopy. ${ }^{1} \mathrm{H}$ NMR spectra show doublets of $\mathrm{H}-5$ protons at 10.98-9.16 ppm region $(\mathrm{J}=0.6 \mathrm{~Hz})$, doublets of the pyrrole $\mathrm{H}-2$ protons in the region of $8.09-8.31 \mathrm{ppm}(\mathrm{J}=2.1 \mathrm{~Hz}), \mathrm{H}-3$ protons resonate as doublets of doublets at 7.15-7.34 ppm $(J=2.1,0.9 \mathrm{~Hz})$. The $\mathrm{H}-9$ protons appear as singlets at 7.76-7.29 ppm. ${ }^{13} \mathrm{C}$ NMR spectra show the signals of C-8 thione carbons at 160.3-173.3 ppm and signals of C-5 carbon at 144.8-150.9 ppm. The characteristic band observed at $1257 \mathrm{~cm}^{-1}$ in IR spectrum of 7 corresponds to the $\mathrm{C}=\mathrm{S}$ group at $\mathrm{C}-8$.

The presence of thione and methyl-carboxylate groups in $\mathbf{8 b}$ enables the cyclisation with hydrazine to afford $2 H$-furo[2',3':4,5]pyrrolo[1,2-d][1,2,4]triazino[3,4-f][1,2,4]triazine-3(4H)-one 9 in $64 \%$ yield after $140 \mathrm{~h}$ heating in ethanol. ${ }^{1} \mathrm{H}$ NMR spectrum shows singlets of $\mathrm{H}-5$ and $\mathrm{H}-12$ protons at 8.79 and 7.17 ppm, respectively. Doublet of $\mathrm{H}-2$ proton appears at $8.01 \mathrm{ppm}(\mathrm{J}=2.1 \mathrm{~Hz})$ and doublet of doublets of $\mathrm{H}-3$ proton is at 7.11ppm $(J=2.4,0.9 \mathrm{~Hz}) \cdot{ }^{13} \mathrm{C}$ NMR spectrum shows the signals of $\mathrm{C}-9$ carbonyl group at $160.6 \mathrm{ppm}$ and signal of C-5 carbon at $154.3 \mathrm{ppm}$.

Antibacterial activity. Compounds 2, 3, 5a, 5c, 6a, 6b, 6c, 6d, 7, 8a, 8b and 9 were screened on their antibacterial activity on $\mathrm{G}^{-}$bacterial species Escherichia coli CCM 7929, Pseudomonas syringae CCM 2114 and $\mathrm{G}^{+}$bacterial species Micrococcus luteus CCM 732, Bacillus pumilus CCM 2218. Antibacterial activity of all tested structures has been compared to standard 6-aminopenicillanic acid (6-APA) as known building block of successful antibiotics - penicillins. The result of antibacterial activity is presented in Table 1. 
Table 1. Antibacterial activity of standard 6-APA and compounds furo[3,2-b]pyrroles $\mathbf{2}$ - 8 on $\mathrm{G}^{-}$bacterial species (Escherichia coli CCM 7929, Pseudomonas syringae CCM 2114) and $\mathrm{G}^{+}$bacterial species (Micrococcus luteus CCM 732, Bacillus pumilus CCM 2218).

\begin{tabular}{ccccc}
\hline Compound & \multicolumn{4}{c}{$\mathrm{MIC} /(\mathrm{mM})$} \\
\cline { 2 - 5 } & M. luteus & B. pumilus & E. coli & P. syringae \\
\hline 6-APA & 4.00 & 7.3 & 3.2 & 5.82 \\
$\mathbf{2}$ & 3.84 & 5.12 & 15.36 & 10.24 \\
$\mathbf{3}$ & 0.64 & 5.12 & 10.24 & 2.56 \\
$\mathbf{5 a}$ & 0.016 & 3.2 & 1.28 & 1.28 \\
$\mathbf{5 c}$ & 2.56 & 2.56 & 2.56 & 2.56 \\
$\mathbf{6 a}$ & 0.024 & 20.48 & 12.88 & 3.84 \\
$\mathbf{6 b}$ & 1.92 & 2.56 & 2.56 & 2.56 \\
$\mathbf{6 c}$ & 20.48 & 20.48 & 20.48 & 20.48 \\
$\mathbf{6 d}$ & 0.64 & 10.24 & 10.24 & 1.6 \\
$\mathbf{7}$ & 15.36 & 20.48 & 15.36 & 15.36 \\
$\mathbf{8 a}$ & $>20.48$ & $>20.48$ & $>20.48$ & $>20.48$ \\
$\mathbf{8 b}$ & 12.24 & 20.48 & 12.24 & 20.48 \\
$\mathbf{9}$ & $>20.48$ & $>20.48$ & $>20.48$ & $>20.48$ \\
\hline
\end{tabular}

As it is shown in Table 1, only compounds $\mathbf{5 a}, \mathbf{5 c}$ and $\mathbf{6 b}$ exhibit higher antibacterial activity than standard 6-APA on all bacterial strains with MIC values in the range $0.016-2.56 \mathrm{mM}$. Moderate antibacterial activity against Micrococcus luteus has been observed for compounds 5a and 6a (MIC values 0.016 and $0.024 \mathrm{mM}$, respectively) and compounds $\mathbf{3}$ and $\mathbf{6} \mathbf{d}$ showed poor antibacterial activity against Micrococcus luteus with MIC value $0.64 \mathrm{mM}$.

From structural point of view, compounds with lower molecular weight expressed a higher measure of antibacterial activity and the derivatization of the $\mathrm{N}-7$ nitrogen atom of triazine ring has been concluded as counter-productive in relation to antibacterial activity. According to Lipinski's rule of five ${ }^{21,22}$ the trend of increasing antibacterial activity indicates the predominance of the hydrogen bond acceptors over the hydrogen bond donors, comparing the results between compounds $\mathbf{2}$ and $\mathbf{3}$. As it is shown in Table 1, all tested compounds were more effective on two $\mathrm{G}^{+}$bacterial species ( $M$. luteus and B. pumilus) than on $\mathrm{G}^{-}$ bacterial targets ( $E$. coli and $P$. syringae CCM 2114), what is typical for inhibitors of bacterial cell wall peptidoglycan synthesis like ??-lactam antibiotics.

\section{Experimental Section}

General. Melting points of products were determined on a Kofler hot plate apparatus and are uncorrected. ${ }^{1} \mathrm{H}$ NMR $/{ }^{13} \mathrm{C}$ NMR spectra were obtained on a $300 \mathrm{MHz} / 75 \mathrm{MHz}$ spectrometer VARIAN GEMINI 2000 in DMSO-d 6 with tetramethylsilane as the internal standard. The infrared spectra were taken on a FTIR IRAffinity-1 spectrophotometer using $\mathrm{KBr}$ technique. Elemental analyses were performed on FlashEA $2000 \mathrm{CHNS/O-OEA}$ analyser. MS spectra were measured at Agilent Technologies 1200 Series apparatus. All solvents were distilled and dried appropriately prior to use. The course of reactions was monitored by TLC in ethyl acetate -hexane. Methyl $4 H$-furo[3,2-b]pyrrole-5-carboxylate (1), 4H-furo[3,2-b]pyrrole-5-carbohydrazide (2), furo[2',3':4,5] 
pyrrolo[1,2- $d][1,2,4]$ triazin-8(7H)-one (5a), and furo[2',3':4,5]pyrrolo[1,2- $d][1,2,4]$ triazine-8(7H)-thione (7) were synthesized following the published procedures ${ }^{1,16}$. The other chemicals were purchased from the suppliers as the highest purity grade. Bacteriological thermostat BT 120 (Czech Republic) was used to the cultivation of samples. All bacterial species it has been purchased from Czech Collection of Microorganisms CCM (Brno, Czech Republic). Microplates have been purchased form VWR, Inc. (Vienna, Austria).

Methyl 4-ethanethioyl-4H-furo[3,2-b]pyrrole-5-carboxylate (4). A solution of methyl 4-acetyl-4H-furo[3,2b]pyrrole-5-carboxylate 3 (1.48 g, $7.14 \mathrm{mmol}$ ) and $\mathrm{P}_{2} \mathrm{~S}_{5}(2.38 \mathrm{~g}, 10.7 \mathrm{mmol})$ in pyridine $(20 \mathrm{~mL})$ was refluxed for 10h. The mixture was cooled, diluted with water $(30 \mathrm{~mL})$ and extracted with chloroform $(2 \times 15 \mathrm{~mL})$. The extract was dried over $\mathrm{MgSO}_{4}$, evaporated and the residue was crystallized from dimethylformamide to give 4 as yellow powder. Yield 60\%, mp > $350{ }^{\circ} \mathrm{C} .{ }^{1} \mathrm{H}$ NMR $\left(300 \mathrm{MHz}, \mathrm{DMSO}-\mathrm{d}_{6}\right) \delta 8.65(\mathrm{~d}, 1 \mathrm{H}, J 2.7 \mathrm{~Hz}, \mathrm{H}-2), 7.98(\mathrm{t}$, $1 \mathrm{H}, J$ 2.9, $0.9 \mathrm{~Hz}, \mathrm{H}-6), 7.54$ (dd, $1 \mathrm{H}, J 2.7,0.9 \mathrm{~Hz}, \mathrm{H}-3), 3.45$ (s, 3H, $\left.\mathrm{CH}_{3}\right), 3.17\left(\mathrm{~s}, 3 \mathrm{H}, \mathrm{CH}_{3}\right)$. The ${ }^{13} \mathrm{C} \mathrm{NMR}$ spectrum was unmeasurable because of the low solubility of 4. Anal. Calcd. for $\mathrm{C}_{10} \mathrm{H}_{9} \mathrm{NO}_{3} \mathrm{~S}(223.25) \mathrm{C} \mathrm{53.80, \textrm {H }}$ 4.06, N, 6.27, S, 14.36. Found: C 53.48, H 4.01, N 5.89, S 14.22\%.

Furo[2',3':4,5]pyrrolo[1,2-d][1,2,4]triazin-8(7H)-ones (5a-5c). Method A. A mixture of 4H-furo[3,2-b]pyrrole5-carbohydrazide $2(0.52 \mathrm{~g}, 3.1 \mathrm{mmol})$ and triethyl orthoformate $(0.46 \mathrm{~g}, 3.1 \mathrm{mmol})$ was refluxed in dry dimethylformamide $\left(3 \mathrm{~mL}\right.$ ) for $3.5 \mathrm{~h}$ (for $5 \mathbf{b}$ : $80{ }^{\circ} \mathrm{C}, 24 \mathrm{~h}$ ). The solution was cooled and the precipitate was filtered off and crystallized from dioxane.

Method B. To the solution of methyl 4-ethanethioyl-4H-furo[3,2-b]pyrrole-5-carboxylate 4 (0.4 g, $1.9 \mathrm{mmol})$ in ethanol $(15 \mathrm{~mL})$ was added hydrazine hydrate $(2.7 \mathrm{~g}, 86 \mathrm{mmol})$. The mixture was heated at $80{ }^{\circ} \mathrm{C}$ for $168 \mathrm{~h}$. The work-up was the same as in Method A.

Furo[2',3':4,5]pyrrolo[1,2-d][1,2,4]triazin-8(7H)-one (5a). ${ }^{15}$ White solid, yield 69\%, mp 284-286 ${ }^{\circ} \mathrm{C} . \mathrm{IR}(\mathrm{KBr})$ $v / \mathrm{cm}^{-1} 3114(\mathrm{NH}), 1641$ (C=O). ${ }^{1} \mathrm{H}$ NMR (300 MHz, DMSO-d $)$ ) $\delta 11.81(\mathrm{~s}, 1 \mathrm{H}, \mathrm{NH}), 8.75(\mathrm{~s}, 1 \mathrm{H}, \mathrm{H}-5), 8.00(\mathrm{~d}, 1 \mathrm{H}, J$ $2.4 \mathrm{~Hz}, \mathrm{H}-2), 7.14$ (s, $1 \mathrm{H}, \mathrm{H}-9), 7.11$ (dd, $1 \mathrm{H}, J 2.4,0.8 \mathrm{~Hz}, \mathrm{H}-3) ;{ }^{13} \mathrm{C} N M R\left(75 \mathrm{MHz}, \mathrm{DMSO}-d_{6}\right) \delta 155.2,149.5$, 148.4, 127.7, 124.8, 123.5, 100.0, 92.4. MS (ES): $m / z$ 176.1 $\left(\mathrm{MH}^{+}\right)$. Anal. Calcd. for $\mathrm{C}_{8} \mathrm{H}_{5} \mathrm{~N}_{3} \mathrm{O}_{2}(175.14) \mathrm{C} 54.86$, H 2.88, N 23.99. Found: C 54.69, H 2.93, N 24.16\%.

5-(Chloromethyl)furo[2',3':4,5]pyrrolo[1,2-d][1,2,4]triazin-8(7H)-one (5b). White solid, yield 75\%, mp 224$226{ }^{\circ} \mathrm{C} .{ }^{1} \mathrm{H}$ NMR $\left(300 \mathrm{MHz}, \mathrm{DMSO}-d_{6}\right) \delta 12.09(\mathrm{~s}, 1 \mathrm{H}, \mathrm{NH}), 7.97(\mathrm{~d}, 1 \mathrm{H}, J 2.1 \mathrm{~Hz}, \mathrm{H}-2), 6.88(\mathrm{~d}, 1 \mathrm{H}, J 2.7 \mathrm{~Hz}, \mathrm{H}-9)$, $6.67(\mathrm{dd}, 1 \mathrm{H}, J 2.1,0.6 \mathrm{~Hz}, \mathrm{H}-3), 5.09\left(\mathrm{~s}, 2 \mathrm{H}, \mathrm{CH}_{2}\right)$. The ${ }^{13} \mathrm{C}$ NMR spectrum was unmeasurable because of the low solubility of 5b. Anal. Calcd. for $\mathrm{C}_{9} \mathrm{H}_{6} \mathrm{ClN}_{3} \mathrm{O}_{2}$ (223.62) C 48.34, H 2.70, N 18.79. Found: C 48.02, H 2.73, N $18.61 \%$.

5-Methylfuro[2',3':4,5]pyrrolo[1,2-d][1,2,4]triazin-8(7H)-one (5c). White solid, yield 71\% $\left(\mathrm{A}^{11}\right), 65 \%(B), \mathrm{mp}$ 258-261 ${ }^{\circ} \mathrm{C}$. IR (KBr) v/cm-1 $3126(\mathrm{NH}), 1633$ (C=0). ${ }^{1} \mathrm{H}$ NMR (300 MHz, DMSO-d 6$) \delta 11.65(\mathrm{~s}, 1 \mathrm{H}, \mathrm{NH}), 7.99(\mathrm{~d}$, $1 \mathrm{H}, J 2.1 \mathrm{~Hz}, \mathrm{H}-2), 7.15$ (dd, $1 \mathrm{H}, J 2.4,0.8 \mathrm{~Hz}, \mathrm{H}-3$ ), 7.10 (d, 1H, J $2.4 \mathrm{~Hz}, \mathrm{H}-9), 2.60$ (s, 3H, $\left.\mathrm{CH}_{3}\right) ;{ }^{13} \mathrm{C} \mathrm{NMR}(75$ $\left.\mathrm{MHz}, \mathrm{DMSO}-d_{6}\right) \delta 155.3,149.8,148.9,135.7,125.6,123.9,101.7,92.9,18.0$. Anal. Calcd. for $\mathrm{C}_{9} \mathrm{H}_{7} \mathrm{~N}_{3} \mathrm{O}_{2}(189.17)$ C 57.14, H 3.73, N 22.21. Found: C 56.76, H 3.41, N 21.62\%.

7-Substituted furo[2',3':4,5]pyrrolo[1,2-d][1,2,4]triazin-8(7H)-ones (6a-6c). Furo[2',3':4,5]-pyrrolo[1,2d] $[1,2,4]$ triazin-8(7H)-one $5 \mathrm{a}(1.5 \mathrm{~g}, 8 \mathrm{mmol})$ was suspended in dimethylformamide $(15 \mathrm{~mL})$ and sodium hydride $(0.42 \mathrm{~g}, 17 \mathrm{mmol})$ was added under stirring. After $15 \mathrm{~min}$, appropriate alkyl halide $\left(\mathrm{CH}_{3} \mathrm{l}, \mathrm{n}-\mathrm{C}_{4} \mathrm{H}_{9} \mathrm{Br}\right.$, $\mathrm{PhCH}_{2} \mathrm{Br}$ ) (14 mmol) was added dropwise and stirring was continued for $2.5 \mathrm{~h}$ at room temperature (for $\mathrm{PhCH}_{2} \mathrm{Br}$ overnight at $55^{\circ} \mathrm{C}$ ). The mixture was then poured into ice water and the precipitate was filtered off and crystallized from ethanol to obtain $6 a-6 c$ as white solids. 
7-Methylfuro[2',3':4,5]pyrrolo[1,2-d][1,2,4]triazin-8(7H)-one (6a). Yield 72\%, mp 210-214 ${ }^{\circ} \mathrm{C} ; \mathrm{IR}(\mathrm{KBr}) \mathrm{v} / \mathrm{cm}^{-1}$ $1641(\mathrm{C}=0) .{ }^{1} \mathrm{H}$ NMR (300 MHz, DMSO-d $) \delta 8.81$ (d, $\left.1 \mathrm{H}, J 0.6 \mathrm{~Hz}, \mathrm{H}-5\right), 7.99$ (d, $1 \mathrm{H}, J 2.4 \mathrm{~Hz}, \mathrm{H}-2$ ), 7.14 (s, $1 \mathrm{H}, \mathrm{H}-$ 9), 7.09 (dd, $1 \mathrm{H}, J$ 2.1, $0.9 \mathrm{~Hz}, \mathrm{H}-3), 3.56\left(\mathrm{~s}, 3 \mathrm{H}, \mathrm{CH}_{3}\right) ;{ }^{13} \mathrm{C} \mathrm{NMR}\left(75 \mathrm{MHz}, \mathrm{DMSO}-d_{6}\right) \delta 154.6,149.9,149.2,127.8$, 124.9, 123.8, 100.6, 93.0, 37.4. Anal. Calcd. for $\mathrm{C}_{9} \mathrm{H}_{7} \mathrm{~N}_{3} \mathrm{O}_{2}$ (189.17) C 57.14, H 3.73, N 22.21. Found: C 57.33, H 3.82, N 22.11\%.

7-Butylfuro[2',3':4,5]pyrrolo[1,2-d][1,2,4]triazin-8(7H)-one (6b). Yield 47\%, mp 115-118 ${ }^{\circ} \mathrm{C} ; \mathrm{IR}(\mathrm{KBr}) \mathrm{v} / \mathrm{cm}^{-1}$ $1643(\mathrm{C}=0) .{ }^{1} \mathrm{H}$ NMR $(300 \mathrm{MHz}$, DMSO-d $) \delta 8.82$ (d, $\left.1 \mathrm{H}, J 0.9 \mathrm{~Hz}, \mathrm{H}-5\right), 7.99(\mathrm{~d}, 1 \mathrm{H}, J 2.4 \mathrm{~Hz}, \mathrm{H}-2), 7.13(\mathrm{~d}, 1 \mathrm{H}, J$ $0.3 \mathrm{~Hz}, \mathrm{H}-9$ ), 7.09 (dd, $1 \mathrm{H}, J$ 2.4, $0.9 \mathrm{~Hz}, \mathrm{H}-3$ ), 3.99 (t, 2H, $\mathrm{CH}_{2}$ ), 1.73 (sextet, 2H, $\mathrm{CH}_{2}$ ), 1.37 (sextet, 2H, $\mathrm{CH}_{2}$ ), $0.93\left(\mathrm{t}, 3 \mathrm{H}, \mathrm{CH}_{3}\right) ;{ }^{13} \mathrm{C}$ NMR $\left(75 \mathrm{MHz}, \mathrm{DMSO}-d_{6}\right) \delta 154.3,150.0,149.3,128.0,124.9,123.8,100.6,93.3,48.3$, 30.5, 19.7, 14.1. MS (ES): $m / z 232.2\left(\mathrm{MH}^{+}\right)$. Anal. Calcd. for $\mathrm{C}_{12} \mathrm{H}_{13} \mathrm{~N}_{3} \mathrm{O}_{2}(231.26) \mathrm{C} 62.33, \mathrm{H} 5.67, \mathrm{~N} 18.17$. Found: C 61.89, H 5.56, N 18.18\%.

7-Benzylfuro[2',3':4,5]pyrrolo[1,2-d][1,2,4]triazin-8(7H)-one (6c). Yield 27\%, mp 184-188 ${ }^{\circ} \mathrm{C} ; \mathrm{IR}(\mathrm{KBr}) \mathrm{v} / \mathrm{cm}^{-1}$ $1641(\mathrm{C}=0) .{ }^{1} \mathrm{H}$ NMR (300 MHz, DMSO-d $)_{6} \delta 8.83(\mathrm{~s}, 1 \mathrm{H}, \mathrm{H}-5), 8.01(\mathrm{~d}, 1 \mathrm{H}, J 2.1 \mathrm{~Hz}, \mathrm{H}-2), 7.33-7.27(\mathrm{~m}, 5 \mathrm{H}, \mathrm{Ph})$,

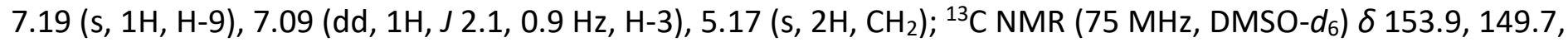
148.7, 137.3, 128.3, 127.8, 127.6, 127.6, 127.3, 127.3, 124.2, 123.5, 100.1, 93.2, 51.6. Anal. Calcd. for $\mathrm{C}_{15} \mathrm{H}_{11} \mathrm{~N}_{3} \mathrm{O}_{2}$ (265.27) C 67.92, H 4.18, N 15.84. Found: C 68.19, H 4.32, N 16.24\%.

Methyl \{8-oxofuro[2',3':4,5]pyrrolo[1,2-d][1,2,4]triazin-7(8H)-yl\}acetate $\quad(6 d) . \quad A \quad$ solution of furo[2',3':4,5]pyrrolo[1,2-d][1,2,4]triazin-8(7H)-one 5 a $(1.0 \mathrm{~g}, 6.0 \mathrm{mmol})$ in dimethylformamide $(18 \mathrm{~mL}) \mathrm{was}$ added to the suspension of $\mathrm{NaH}(0.21 \mathrm{~g}, 8.55 \mathrm{mmol})$ in dimethylformamide $(16 \mathrm{~mL})$. After stirring at room temperature for $30 \mathrm{~min}$, the mixture was cooled to $0{ }^{\circ} \mathrm{C}$ and the methyl chloroacetate $(1.54 \mathrm{~g}, 14.3 \mathrm{mmol})$ was added dropwise. The mixture was stirred at room temperature for $6 \mathrm{~h}$ and then poured into ice water $(30 \mathrm{~mL})$, the precipitate was filtered off and crystallized from ethanol to give $\mathbf{6 d}$ as white solid. Yield $45 \%, \mathrm{mp} 175-180$ ${ }^{\circ} \mathrm{C}$; IR (KBr) v/cm ${ }^{-1} 1736,1650$ (C=O). ${ }^{1} \mathrm{H}$ NMR (300 MHz, DMSO-d 6$) \delta 8.83(\mathrm{~d}, 1 \mathrm{H}, J 0.9 \mathrm{~Hz}, \mathrm{H}-5), 8.01(\mathrm{~d}, 1 \mathrm{H}, J$ $2.4 \mathrm{~Hz}, \mathrm{H}-2), 7.20$ (d, 1H, J $0.6 \mathrm{~Hz}, \mathrm{H}-9), 7.09$ (dd, $1 \mathrm{H}, J 2.4,0.6 \mathrm{~Hz}, \mathrm{H}-3), 4.77\left(\mathrm{~s}, 2 \mathrm{H}, \mathrm{CH}_{2}\right), 3.67\left(\mathrm{~s}, 3 \mathrm{H}, \mathrm{CH}_{3}\right) ;{ }^{13} \mathrm{C}$ NMR $\left(75 \mathrm{MHz}\right.$, DMSO-d $\left.d_{6}\right) \delta 168.2,153.7,149.7,148.3,127.5,123.6,123.5,99.8,93.2,51.7$, 50.1. Anal. Calcd. for $\mathrm{C}_{11} \mathrm{H}_{9} \mathrm{~N}_{3} \mathrm{O}_{4}$ (247.21) C 53.44, $\mathrm{H}$ 3.67, N 17.00. Found: C 52.77, H 4.02, N 17.79\%.

7-Acetylfuro[2',3':4,5]pyrrolo[1,2-d][1,2,4]triazin-8(7H)-one (6e). A solution of furo[2',3':4,5]pyrrolo[1,2d] $[1,2,4]$ triazin- $8(7 \mathrm{H})$-one $5 \mathrm{a}(1.1 \mathrm{~g}, 6.3 \mathrm{mmol})$ in acetic anhydride $(15 \mathrm{~mL})$ was refluxed for $1.5 \mathrm{~h}$. After cooling, the solid precipitate was filtered off and crystallized from acetone to obtain $6 \mathrm{e}$ as white solid. Yield $53 \%, \mathrm{mp}$ 242-245 ${ }^{\circ} \mathrm{C}$; IR ( $\left.\mathrm{KBr}\right) v / \mathrm{cm}^{-1} 1745,1662(\mathrm{C}=0) .{ }^{1} \mathrm{H}$ NMR (300 MHz, DMSO-d 6 ) $\delta 8.83(\mathrm{~d}, 1 \mathrm{H}, J 0.3 \mathrm{~Hz}, \mathrm{H}-5), 8.09$ (d, $1 \mathrm{H}, J 2.4 \mathrm{~Hz}, \mathrm{H}-2), 7.39$ (t, 1H, J $0.6 \mathrm{~Hz}, \mathrm{H}-9), 7.11$ (dd, 1H, J 2.1, 0.9 Hz, H-3), $2.59\left(\mathrm{~s}, 3 \mathrm{H}, \mathrm{CH}_{3}\right) ;{ }^{13} \mathrm{C} \mathrm{NMR}$ (DMSO-d $)_{6} \delta 170.6,154.4,151.6,149.2,128.6,125.7,124.3,100.7,97.6,26.9$. Anal. Calcd. for $\mathrm{C}_{10} \mathrm{H}_{7} \mathrm{~N}_{3} \mathrm{O}_{3}$ (217.18) C 55.30, H 3.25, N 19.35. Found: C 55.01, H 3.31, N 19.64\%.

Furo[2',3':4,5]pyrrolo[1,2-d][1,2,4]triazine-8(7H)-thione (7). ${ }^{15}$ A mixture of compound 5a $(1.5 \mathrm{~g}, 8.5 \mathrm{mmol})$ and $\mathrm{P}_{2} \mathrm{~S}_{5}(1.9 \mathrm{~g}, 8.5 \mathrm{mmol})$ was stirred and refluxed in pyridine $(8.6 \mathrm{~mL})$ for $5 \mathrm{~h}$. The mixture was poured into hot water $(30 \mathrm{~mL})$ and the precipitate was filtered off and crystallized from dioxane to give 7 as pale brown solid. Yield 85\%, mp 268-270 ${ }^{\circ} \mathrm{C}$; IR ( KBr) v/cm ${ }^{-1} 3126(\mathrm{NH}), 1257(\mathrm{C}=\mathrm{S}) ;{ }^{1} \mathrm{H}$ NMR (300 MHz, DMSO-d 6 ) $\delta 13.29(\mathrm{~s}$, $1 \mathrm{H}, \mathrm{NH}), 9.16(\mathrm{~d}, 1 \mathrm{H}, J 0.6 \mathrm{~Hz}, \mathrm{H}-5), 8.09$ (d, 1H, J $2.1 \mathrm{~Hz}, \mathrm{H}-2), 7.29$ (d, 1H, J $2.4 \mathrm{~Hz}, \mathrm{H}-9$ ), 7.15 (dd, 1H, J 2.1, 0.9 $\mathrm{Hz}, \mathrm{H}-3) ;{ }^{13} \mathrm{C}$ NMR $(75 \mathrm{MHz}$, DMSO-d $) \delta 173.1,150.5,149.4,131.7,130.5,123.9,100.2,95.3$. MS (ESI+): $\mathrm{m} / \mathrm{z}$ 192.1 (MH+). Anal. Calcd. for $\mathrm{C}_{8} \mathrm{H}_{5} \mathrm{~N}_{3} \mathrm{OS}$ (191.21) C 50.25, H 2.64, N 21.98, S 16.77. Found: C 50.48, H 2.62, N $22.14, \mathrm{~S} 16.89 \%$.

7-Methylfuro[2',3':4,5]pyrrolo[1,2-d][1,2,4]triazine-8(7H)-thione (8a). Method A: Furo[2',3':4,5]pyrrolo[1,2d] $[1,2,4]$ triazine- $8(7 H)$-thione $7(0.3 \mathrm{~g}, 1.6 \mathrm{mmol})$ was suspended in dimethylformamide $(3 \mathrm{~mL})$ and sodium 
hydride $(0.07 \mathrm{~g}, 3.1 \mathrm{mmol})$ was added under stirring at room temperature for $1 \mathrm{~h}$. Methyl iodide $(0.44 \mathrm{~g}, 3.1$ $\mathrm{mmol}$ ) was added dropwise and stirring was continued for $4 \mathrm{~h}$. The mixture was then poured into ice water (30 $\mathrm{mL}$ ), the precipitate was filtered of and crystallized from dimethylformamide to give $8 \mathrm{a}$ as yellow solid.

Method B: The mixture of 7-methylfuro[2',3':4,5]pyrrolo[1,2-d][1,2,4]triazin-8(7H)-one $6 a(1 \mathrm{~g}, 5.7 \mathrm{mmol})$ and $\mathrm{P}_{2} \mathrm{~S}_{5}(1.27 \mathrm{~g}, 5.7 \mathrm{mmol})$ was stirred and refluxed in pyridine $(10 \mathrm{~mL})$ for $5 \mathrm{~h}$. The mixture was poured into hot water $(20 \mathrm{~mL})$ and extracted with chloroform $(2 \times 10 \mathrm{~mL})$. Organic layer was separated, dried $\left(\mathrm{Na}_{2} \mathrm{SO}_{4}\right)$ and the solvent was evaporated. The work-up was the same as in Method A. Yield $76 \%(\mathrm{~A}), 67 \%(\mathrm{~B}), \mathrm{mp}>360{ }^{\circ} \mathrm{C} .{ }^{1} \mathrm{H}$ NMR (300 MHz, DMSO-d $\left.d_{6}\right) \delta 10.95$ (s, 1H, H-5), 8.31 (d, 1H, J 2.4 Hz, H-2), 7.76 (s, 1H, H-9), 7.34 (dd, 1H, J 2.4, $0.9 \mathrm{~Hz}, \mathrm{H}-3), 4.17\left(\mathrm{~s}, 3 \mathrm{H}, \mathrm{CH}_{3}\right) ;{ }^{13} \mathrm{C}$ NMR $\left(75 \mathrm{MHz}\right.$, DMSO- $\left.d_{6}\right) \delta 162.3,157.7,156.5,144.8,130.9,125.9,106.1$, 99.7, 51.8. Anal. Calcd. for $\mathrm{C}_{9} \mathrm{H}_{7} \mathrm{~N}_{3} \mathrm{OS}$ (205.24) C 52.67, H 3.44, N 20.47, S 15.62. Found: C 52.91, H 3.49, N 20.58, S $15.88 \%$.

Methyl (8-thioxofuro[2',3':4,5]pyrrolo[1,2-d][1,2,4]triazin-7(8H)-yl)acetate (8b). The mixture of compound $6 \mathrm{~d}(2.47 \mathrm{~g}, 10 \mathrm{mmol})$ and $\mathrm{P}_{2} \mathrm{~S}_{5}(2.67 \mathrm{~g}, 12 \mathrm{mmol})$ was stirred and refluxed in pyridine $(14 \mathrm{~mL})$ for $9 \mathrm{~h}$. The mixture was poured into hot water $(20 \mathrm{~mL})$, the precipitate was filtered off and crystallized from dioxane to give $8 \mathbf{b}$ as yellow solid. Yield $71 \%, \mathrm{mp} 168-172{ }^{\circ} \mathrm{C}$. ${ }^{1} \mathrm{H}$ NMR $\left(300 \mathrm{MHz}\right.$, DMSO- $\left.d_{6}\right) \delta 9.25(\mathrm{~s}, 1 \mathrm{H}, \mathrm{H}-5), 8.11(\mathrm{~d}, 1 \mathrm{H}$, J $2.4 \mathrm{~Hz}, \mathrm{H}-2), 7.36(\mathrm{~s}, 1 \mathrm{H}, \mathrm{H}-9$ ), 7.15 (dd, $1 \mathrm{H}, J 2.4,0.9 \mathrm{~Hz}, \mathrm{H}-3), 5.32\left(\mathrm{~s}, 2 \mathrm{H}, \mathrm{CH}_{2}\right), 3.57\left(\mathrm{~s}, 3 \mathrm{H}, \mathrm{CH}_{3}\right) .{ }^{13} \mathrm{C}$ NMR $(75$ $\mathrm{MHz}$, DMSO- $\left.d_{6}\right) \delta 173.3,167.4,150.9,131.6,130.6,127.9,100.4,96.8,93.6,56.7$, 52.3. Anal. Calcd. for $\mathrm{C}_{11} \mathrm{H}_{9} \mathrm{~N}_{3} \mathrm{O}_{3} \mathrm{~S}$ (263.27) C 50.18, H 3.45, N 15.96, S, 12.18. Found C 49.97, H 3.56, N 14.32, S 12.06\%.

2H-Furo[2',3':4,5]pyrrolo[1,2-d][1,2,4]triazino[3,4-f][1,2,4]triazine-3(4H)-one (9). Hydrazine hydrate $(6 \mathrm{~g}, 120$ $\mathrm{mmol})$ was added to the solution of $8 \mathbf{b}(2.11 \mathrm{~g}, 8 \mathrm{mmol})$ in ethanol $(9.5 \mathrm{~mL})$ and the mixture was stirred $140 \mathrm{~h}$ under reflux. After cooling the solid was filtered off, washed with water and crystallized from dioxane to give $\mathbf{9}$ as yellow solid. Yield: $64 \%, \mathrm{mp} 247-250^{\circ} \mathrm{C} .{ }^{1} \mathrm{H}$ NMR $\left(300 \mathrm{MHz}\right.$, DMSO- $\left.d_{6}\right) \delta 10.72(\mathrm{~s}, 1 \mathrm{H}, \mathrm{NH}), 8.79(\mathrm{~s}, 1 \mathrm{H}, \mathrm{H}-5)$, 8.01 (d, $1 \mathrm{H}, J 2.1 \mathrm{~Hz}, \mathrm{H}-2), 7.17$ (s, $1 \mathrm{H}, \mathrm{H}-12), 7.11$ (dd, $1 \mathrm{H}, J 2.4,0.9 \mathrm{~Hz}, \mathrm{H}-3), 4.55$ (s, 2H, $\mathrm{CH}_{2}$ ). ${ }^{13} \mathrm{C}$ NMR (75 $\mathrm{MHz}$, DMSO-d $\left.d_{6}\right) \delta 160.3,154.3,149.8,147.9,127.8,124.5,100.1,93.1,90.2,50.3$. Anal. Calcd. for $\mathrm{C}_{10} \mathrm{H}_{7} \mathrm{~N}_{5} \mathrm{O}_{2}$ (229.20) C 52.40, H 3.08, N 30.56. Found C 52.09, H 3.13, N 30.78\%.

Determination of Minimal Inhibition Concentration (MIC) parameters. On determination of MIC parameters there were used sterile microplates (type P), where the suspension of bacterial species in nutrient broth medium with dissolved tested compound has been achieved by convenient dilution method using automatic multichannel pipets. The concentration from the column 1 to column 12 was in the decreasing order: 20.48 $\mathrm{mM} ; 10.24 \mathrm{mM} ; 5.12 \mathrm{mM} ; 2.56 \mathrm{mM} ; 1.28 \mathrm{mM} ; 0.64 \mathrm{mM} ; 0.32 \mathrm{mM} ; 0.16 \mathrm{mM} ; 0.08 \mathrm{mM} ; 0.04 \mathrm{mM} ; 0.02 \mathrm{mM}$ and $0.01 \mathrm{mM}$. The inoculum concentration of bacterial species suspension in nutrient broth medium was before filling set by McFarland Densitometer DEN-1 (UK) on the value 0.1. The first two rows $\mathbf{A}$ and $\mathbf{B}$ were occupied by the standard 6-aminopenicilanic acid (6-APA) on each microplate and the tested compounds were in the rows C-G.

After $24 \mathrm{~h}$ of cultivation at $37{ }^{\circ} \mathrm{C}$ in the bacteriological thermostat $30 \mu \mathrm{l}$ of $0.03 \%$ solution of Thiazolyl Blue (MTT) in water was added to each well and incubated again for $1 \mathrm{~h}$ under the same conditions. Bacterial proliferation led to the production of bacterial mitochondrial dehydrogenase, which turned yellow colored solution of MTT to intensively blue colored formazan product. MIC parameter was identified visually as the last not colored well in the row. All experiments were carried out as triplicate. 


\section{Acknowledgements}

This work was supported by the Slovak Research Agency under the contracts No. VEGA 1/0534/16 and VEGA 1/0634/13.

http://dx.doi.org/

\section{References}

1. Krutošíková, A.; Dandárová, M.; Chylová, J.; Vegh, D. Monatsh. Chem. 1992, 123, 807-815. http://dx.doi.org/10.1007/BF00812330

2. Beccalli, E. M.; Broggini, G.; Martinelli, M.; Sottocornola, S. Synthesis 2008, 136-140. http://dx.doi.org/10.1055/s-2007-990947

3. Zhao, H.; Koenig, S. G.; Dankwardt, J. W.; Singh, S. P. Org. Process Res. Dev. 2014, 18, 198-204. http://dx.doi.org/10.1021/op4001737

4. Raffa, D.; Maggio, B.; Raimondi, V. M.; Cascioferro, S.; Plescia, F.; Cancemi, G.; Daidone, G. Eur. J. Med. Chem. 2015, 97, 732-746.

http://dx.doi.org/10.1016/j.ejmech.2014.12.023

5. Sparey, T.; Abeywickrema, P.; Almond, S.; Brandon, N.; Byrne, N.; Campbell, A.; Hutson, P. H.; Jacobson, M.; Jones, B.; Munshi, S.; Pascarella, D.; Pike, A.; Prasad, G. S.; Sachs, N.; Sakatis, M.; Sardana, V.; Venkatraman, S.; Young, M. B. Bioorg. Med. Chem. Lett. 2008, 18, 3386-3391. http://dx.doi.org/10.1016/j.bmcl.2008.04.020

6. Kawasima, Y.; Amanuma, F.; Sato, M.; Okuyama, S.; Nakashima, Y.; Sota, K.; Moriguchi, I. J. Med. Chem. 1986, 29, 2284-2290. http://dx.doi.org/10.1021/jm00161a026

7. Zhuang, H. S.; Lin, Ch. Y.; Chou, Ch. L.; Hsu, H. M.; Lin, Y. H.; Huang, H. Ch.; Lien, Ch. J.; Kuo, CH. S; Huang, J. L. Eur. J. Med. Chem. 2013, 66, 466-479.

http://dx.doi.org/10.1016/j.ejmech.2013.06.012

8. Umezawa, K.; Nakamura, Y.; Makino, H.; Citterio, D.; Suzuki, K. J. Am. Chem. Soc. 2008, 130, $1550-1551$. http://dx.doi.org/10.1021/ja077756j

9. Issartel, V; Spehner, V; Coudert, P., Seilles, E; Couquelet, J. Bioorg. Med. Chem. 1998, 6, 349-354. http://dx.doi.org/10.1016/S0968-0896(97)10052-9

10. Astakhina, V.; Voievudskyi, M.; Kharchenko, O.; Novikov, V.; Komarovska-Porohnyavets, E.; Petukhova, O. J. Heterocycl. Chem. 2016, 53, 421-428.

http://dx.doi.org/10.1002/jhet.2204

11. George, D. M.; Breinlinger, E. C.; Friedman, M.; Zhang, Y.; Wang, J.; Argiriadi, M.; Bansal-Pakala, P.; Barth, M.; Duignan, D. B.; Honore, P.; Lang, Q.; Mittelstadt, S.; Potin, D.; Rundell, L.; Edmunds, J. J. J. Med. Chem. 2015, 58, 222-236.

http://dx.doi.org/10.1021/jm500669m

12. Schoenfeld, R. C.; Bourdet, D. L.; Brameld, K. A.; Chin, E.; De Vicente, J.; Fung, A.; Harris, S. F.; Lee, E. K.; Le Pogam, S.; Leveque, V.; Li, J.; Lui, A. S.-T.; Najera, I.; Rajyaguru, S.; Sangi, M.; Steiner, S.; Talamas, F. X.; Taygerly, J. P.; Zhao, J. J. Med. Chem. 2013, 56, 8163-8182. 
13. Zhan, P.; Li, X.; Li, Z.; Chen, X.; Tian, Y.; Chen, W.; Liu, X.; Pannecouque, C.; De Clercq, E.: Bioorg. Med. Chem. Lett. 2012, 22, 7155-7162.

http://dx.doi.org/10.1016/j.bmcl.2012.09.062

14. El-Gendy, A. A.; Said, M. M.; Ghareb, N.; Mostafa, Y. M.; El-Ashry, E. S. H. Arch. Pharm. 2008, 341, 294-300.

http://dx.doi.org/10.1002/ardp.200700161

15. Jiang, J.-k.; Boxer, M. B.; Vander Heiden, M. G.; Shen, M.; Skoumbourdis, A. P.; Southall, N.; Veith, H.; Leister, W.; Austin, C. P.; Park, H. W.; Inglese, J.; Cantley, L. C.; Auld, D. S.; Thomas, C. J. Bioorg. Med. Chem. Lett. 2010, 20, 3387-3393. DOI:10.1016/j.bmcl.2010.04.015

16. Krutošíková, A.; Kováč, J.; Dandárová, M. Collect. Czech. Chem. Commun. 1984, 49, 65-70. http://dx.doi.org/10.1135/cccc19840065

17. Kudelko, A.; Zielinski, W.; Ejsmont, K.: Tetrahedron, 2011, 67, 7838-7845. http://dx.doi.org/10.1016/i.tet.2011.07.047

18. Andersen, T. P.; Ghattas, A.-B. A. G.; Lawesson, S. O. Tetrahedron, 1983, 39, 3419-3427. http://dx.doi.org/10.1016/S0040-4020(01)91595-9

19. Gajdoš, P.; Pavlíková, S.; Bureš, F.; Krutošíková, A. Cent. Eur. J. Chem. 2005, 311- 325. http://dx.doi.org/10.2478/BF02475999

20. Krutošíková, A.; Král’ovičová, E.; Kováč, J.; Dandárová, M. Collect. Czech. Chem. Commun. 1986, 51, 14551461.

http://dx.doi.org/10.1135/cccc19861455

21. Lipinski, C. A.; Lombardo, F. ; Dominy, B.W. ; Feeney, P.J. Adv. Drug Deliv. Rev. 2001, 46, 3 -26. http://dx.doi.org/10.1016/S0169-409X(00)00129-0

22. Lipinski, C. A. Drug Discov. Today: Technol. 2004, 1, 337-341. https://doi.org/10.1016/j.ddtec.2004.11.007 